\title{
Tularemia: a re-emerging tick-borne infectious disease
}

\author{
Derya Karataş Yeni ${ }^{1}$ (D) $\cdot$ Fatih Büyük ${ }^{2}$ (D) Asma Ashraf $^{3}$ (D) $\cdot$ M. Salah ud Din Shah ${ }^{4}$ (D)
}

Received: 5 June 2020 / Accepted: 18 September 2020 / Published online: 28 September 2020

(C) Institute of Microbiology, Academy of Sciences of the Czech Republic, v.v.i. 2020

\begin{abstract}
Tularemia is a bacterial disease of humans, wild, and domestic animals. Francisella tularensis, which is a Gram-negative coccobacillus-shaped bacterium, is the causative agent of tularemia. Recently, an increase in the number of human tularemia cases has been noticed in several countries around the world. It has been reported mostly from North America, several Scandinavian countries, and certain Asian countries. The disease spreads through vectors such as mosquitoes, horseflies, deer flies, and ticks. Humans can acquire the disease through direct contact of sick animals, consumption of infected animals, drinking or direct contact of contaminated water, and inhalation of bacteria-loaded aerosols. Low infectious dose, aerosol route of infection, and its ability to induce fatal disease make it a potential agent of biological warfare. Tularemia leads to several clinical forms, such as glandular, ulceroglandular, oculoglandular, oropharyngeal, respiratory, and typhoidal forms. The disease is diagnosed through the use of culture, serology, or molecular methods. Quinolones, tetracyclines, or aminoglycosides are frequently used in the treatment of tularemia. No licensed vaccine is available in the prophylaxis of tularemia and this is need of the time and high-priority research area. This review mostly focuses on general features, importance, current status, and preventive measures of this disease.
\end{abstract}

Keywords Francisella tularensis · Tularemia $\cdot$ Vector-borne infection

$\begin{array}{ll}\text { Abbreviations } & \\ \text { ASM } & \text { American Society for Microbiology } \\ \text { AVMA } & \text { American Veterinary Medical Association } \\ \text { CDC } & \begin{array}{l}\text { Centers for Disease Control and Prevention } \\ \text { The European Centre for Disease Prevention } \\ \text { and Control }\end{array} \\ \text { ECDC } & \begin{array}{l}\text { Global Infectious Diseases and Epidemiology } \\ \text { GIDEON }\end{array} \\ \text { LVS } & \text { Network } \\ \text { MALDI-To vaccine strain } \\ \text { MS } & \text { time-of-flight mass spectrometry }\end{array}$

Fatih Büyük

fatihbyk08@hotmail.com

1 Veterinary Control Central Research Institute, Bacterial Disease Laboratory, Ankara, Turkey

2 Department of Microbiology, Veterinary Faculty, University of Kafkas, Kars, Turkey

3 Department of Zoology, Government College University, Faisalabad, Pakistan

4 Nuclear Institute for Agriculture and Biology (NIAB), Faisalabad, Pakistan
MLVA
TBD
USA
USSR

\author{
Multilocus VNTR analysis \\ Tick-borne disease \\ United States of America \\ Union Soviet Socialist Republics
}

\section{Introduction}

Francisella tularensis is a pleomorphic, Gram-negative, nonmotile, and non-spore-forming intracellular bacterium. It was isolated for the first time in Tulare county of California in 1911. Tularemia is also known as Pahvant Valley plague, rabbit fever, deer fly fever, and Ohara's fever. The causative organism of tularemia has been isolated from man and a wide range of animal species including mammals, birds, fishes, amphibians, arthropods, and protozoa. It is also revealed that isolation of this bacterium may represent colonization without infection as the presence of the organism has been reported from animals without any disease symptoms. F. tularensis is taxonomically divided into several sub-species, including tularensis (also known as type A), holarctica (also known as type B), mediaasiatica, and novicida. Cottontail rabbits (Sylvilagus spp.) and ticks are the main reservoirs of type A (Telford and Goethert 2020). On the other hand, aquatic 
rodents (muskrats and beavers) are believed to spread type B. The terrestrial cycle of type A strains and aquatic cycle of type $B$ strains have been described in the USA, but remain debated (Hansen et al. 2011). They cannot be extrapolated to the rest of the world. In fact, terrestrial and aquatic cycles can also be found in Europe and Asia, where only type B strains are found (Carvalho et al. 2014). In human cases, type A is found more virulent than type B (Mörner 1992; Ellis et al. 2002). Transmission of $F$. tularensis to humans is through the handling of infected animals, consumption of contaminated food or water, vector bites (ticks, flies, and mosquitoes), contact with aquatic environment, and inhalation of aerosols (Hopla 1974; Pearson 1998). The clinical manifestation of tularemia depends on the route of acquisition. A conspicuously enlarged tender node arises when bacteria are acquired through the skin or oral mucous membranes. Inhalation of $F$. tularensis primarily results in pneumonia, which may be associated with deep mediastinal lymphadenopathy (Anda et al. 2007).

Tularemia has been reported in most countries of the northern hemisphere and most frequently in the Scandinavian countries, northern America, Japan, and Russia. The incidence is high especially in North America and the Nordic countries. Moreover, tularemia has recently been reported from Turkey, Yugoslavia, Spain, Kosovo, and Switzerland. In countries with a relatively high incidence of the disease, the geographical distribution is uneven. The reasons underlying the geographical restriction of outbreaks are not known. However, this is probably due to increased awareness and improved diagnosis rather than to the global spread of the bacterium. Ultimately, tularemia is thought to be more widely distributed than was previously thought (Sjöstedt 2007b; Gürcan 2014).

Tularemia is a zoonotic disease and rodents, hares, and rabbits are important sources of human infection (Mörner 1992). Tularemia has recently become a significant reemerging disease in the world because of the important role of bacteria in biological terrorism agents. The low infectious dose, easy and high dissemination with aerosols, and ability to induce fatal disease make $F$. tularensis a potential agent of biological warfare. Hence, tularemia has been classified by the Centers for Disease Control and Prevention (CDC) as a category A biological weapon (Dennis et al. 2001; Maurin 2015).

\section{Etiology}

Francisella tularensis is the causative agent of tularemia. The bacterium is an aerobic, Gram-negative, intracellular organism, having bipolar morphology. It harbors a cell wall rich in fatty acids and besieged by a semi-virulent capsule. The Francisella genus could be divided into two main genetic clades; one including $F$. tularensis, $F$. novicida, and $F$. hispaniensis, and another including $F$. philomiragia and $F$. noatunensis (Sjödin et al. 2012). F. tularensis is one of the members of Francisella genus in terrestrial animals and contains four subtypes. These are F. tularensis subsp. tularensis (type A), F. tularensis subsp. holarctica (type B), F. tularensis subsp. novicida, and $F$. tularensis subsp. mediaasiatica. Among these, F. tularensis subsp. tularensis and $F$. tularensis subsp. holarctica are considered major etiological agents of tularemia in humans. While $F$. tularensis subsp. novicida is very rarely associated with human infections (Sjöstedt 2005), human infection due to $F$. tularensis subsp. mediaasiatica has never been documented in the published literatures.

\section{F. tularensis subsp. tularensis}

F. tularensis subsp. tularensis is the causative agent of type A tularemia, which presents exclusively in North America. Type $\mathrm{A}$ is a more virulent subspecies of the microorganism, which is responsible for the majority of infections in humans (Pilo 2018). This disease is also known as rabbit fever because it was mostly found in hunters of rabbits and hares. Rabbits (Sylvilagus spp.) and hares (Lepus spp.) were found to be the carriers/reservoirs of $F$. tularensis subsp. tularensis (Sjöstedt 2007a). The emergence of tularemia occurred in the USA with the import of the rabbits (Sylvilagus floridanus) in the late 1950s. Initially, few cases were reported in the USA then it became an endemic disease (Belding and Merrill 1941). Tularemia was much more common in the USA in the early part of the twentieth century. Tularemia, which had almost 1000 cases annually in the 1950 s, is now around 250 cases annually (Center for Disease Control and Prevention 2018). F. tularensis subsp. tularensis is divided into 2 distinct subpopulations as A.I. (A-east) and A.II. (A-west) by MLVA analysis, considering the geographic distribution, disease outcome, and transmission. A.I. occurs primarily in the central and eastern United States, while A.II. occurs primarily in the western United States. Moreover, it is suggested that A.II. infections are less severe than either type B or A.I. infections (Johansson et al. 2004; Staples et al. 2006).

\section{F. tularensis subsp. holarctica}

In Europe, F. tularensis subsp. holarctica is the leading cause of tularemia. Moreover, it has also been reported from North America (Mörner and Addison 2001). Tularemia is primarily a zoonotic disease; most human infections occur through direct or indirect contact with infected animals. Arthropodborne and water-borne infections are less frequent except in specific areas, e.g., Sweden and Turkey (Ohlin 1942; Kılıç et al. 2015). Outbreaks mostly occur initially in rodents followed by the epidemics in humans. It was also found that the voles (Microtus spp.) and water voles (Arvicola terrestris) are the carriers/reservoirs of $F$. tularensis subsp. holarctica 
(Olsuf'ev and Shlygina 1979). Water reservoirs are among major sources of infection as the infected voles excrete the bacteria in urine and contaminate the water (Bell and Stewart 1975). Water-borne infection of $F$. tularensis subsp. holarctica is more important in humans compared with the vector-borne disease because mostly the disease spreads in humans through contact with contaminated water or infected animals (Reintjes et al. 2002).

Tick-borne tularemia cases are found in almost all disease endemic areas but tularemia cases occurring through flies or mosquitoes bites have only been reported from specific geographic areas. Important vectors responsible for the spread of F. tularensis subsp. holarctica are hard ticks (Ixodidae), biting flies, and mosquitoes. In Europe, important tick vectors are D. nuttalli, D. marginatus, I. ricinus, D. reticulatus, and Hymaphysalus concinna (Gurycova et al. 1995). An outbreak in humans was reported from Sweden and Finland. It was found during investigations that wild rodents were carriers of the pathogen while mosquitoes were acting as a vector in the spread of the disease (Eliasson et al. 2002). Spread of the disease through mosquitoes can also be possible by infection of mosquitoes at the larval stage from the contaminated aquatic environment and transstadial transmission of $F$. tularensis up to the adult stage. Moreover, different species of mosquitoes (Aedes, Culex, and Anopheles) can be involved in the spread of disease (Petrishcheva 1965).

\section{Epidemiology}

\section{Species susceptibility of $F$. tularensis}

Francisella tularensis is a bacterium with such a wide host range that (Hopla and Hopla 1994) made a well-fitted definition for it as "Few, if any, zoonotic disease agents have a broader host distribution than F. tularensis." So, indeed, the organism is deserving of this definition since it infects more than 100 species of wild and domestic vertebrates and over 100 species of invertebrates. The most important vertebrates, which are assumed as the primary vectors of $F$. tularensis, are Lagomorpha, Rodentia, and Sciuromorpha. Lagomorphs (cottontail rabbits), hares, jackrabbits, muskrats, beavers, and a variety of rodents such as voles, field, mice, squirrels, and lemmings are common wild animal hosts of the organism. Among domestic animals, tularemia occurs in sheep, cats, rabbits, dogs, pigs, and horses. Birds are considered resistant to tularemia but a variety of species has acquired natural infections. The more striking of that is a description about the infection with $F$. tularensis in two birds of prey (a roughlegged buzzard (Buteo lagopus) and a Ural owl (Strix uralensis)) in Sweden (Mörner and Mattsson 1983). The other was just an assumption that the birds may act as a vector, carrying the $F$. tularensis on their claws or beak without any infection that was asserted following the attack of common buzzards (Buteo buteo) on some jogger people in the Kanton Aargau in Switzerland (Ehrensperger et al. 2018).

\section{Routes of transmission}

Transmission of $F$. tularensis to humans is through the handling of infected animals, consumption of contaminated food or water, vector bites (such as ticks, flies, and mosquitoes), contact with aquatic environment, and inhalation of aerosols (Hopla 1974; Pearson 1998). Therefore, it is also noticed that the disease was found mostly in humans working/living close to animals and agricultural lands (Berdal et al. 1996; Eliasson et al. 2006). F. tularensis can be transmitted to humans via the skin when they handled infected or live animals' tissue, skin, or blood. Eating undercooked animal tissues or foods and consumption of water that have been contaminated by infected carcasses or excretions can infect people. Some human infections with $F$. thlarensis were linked to immersion in water. Respiratory infections sometimes occur in agricultural occupations such as piling hay or mowing lawns especially running over infected animals or carcasses. Arthropod vectors such as ticks, biting flies, and mosquitoes are also important in the transmission of tularemia to humans. Person-to-person transmission has not been reported. The enter site and transmission route of infection determine the clinical form of the disease.

\section{Role of vectors in transmission}

The infection is transmitted among mammalian hosts by a variety of arthropod vectors. In the case of USA, most common vectors are biting flies in Utah, Nevada, and California, while ticks are the most important vectors around the Rocky Mountains (Ellis et al. 2002). In the former Soviet Union, it was reported that both mosquitoes (Aedes, Culex, and Anopheles) and ticks (Ixodes) transmit the infection (Ellis et al. 2002). In Japan, no arthropod-borne cases were reported before 1951, whereas several arthropod-borne cases were reported between 1972 and 1998. The disease reported to spread during winter by direct contact with infected hares was biphasic. Moreover, arthropod-borne cases were reported mostly from spring to autumn (Ohara et al. 1998). In Central Europe, D. reticulatus and I. ricinus ticks were reported as important vectors for transmission of the disease (Hubalek et al. 1996; Hubalek et al. 1998). It was also observed that during an outbreak, mosquito bites could be the major risk factor for the rapid spread of the disease (Eliasson et al. 2002).

\section{Water as a source of tularemia}

Francisella tularensis can survive and infectivity persists in water sources through amoebae and primary hosts such as 
beavers, muskrats, or lemmings (Gürcan 2014). The contamination of waters is primarily due to urine and feces from infected animals or the carcasses of animals dying from tularemia. It is experimentally estimated that one infected water vole or mouse can contaminate up to 500,000 1 of water with $F$. tularensis (Pavlovsky 1966). The organism can survive at infective levels in water for more than a month and may become an important vehicle for contamination or infection of biting insects, vertebrate animals, and humans. Water-borne tularemia outbreaks and sporadic cases have been reported worldwide in the last decades. These infections represent a major public health and military challenge. Humans can be infected by $F$. tularensis through not only consumption the water but also use of contaminated water and various aquatic activities such as swimming, canyoning, and fishing. Water-borne tularemia was first described in the 1930s in the USSR (Karpoff and Antonoff 1936). However, it gained momentum as usual and the cases linked with drinking water increased in the last 20 years in many countries such as Turkey, Kosovo, Bulgaria, Georgia, Norway, Sweden, Italy, and Germany. In Turkey, all human cases originated from water sources and all of these are almost related to consumption of drinking water. Large outbreaks affecting more than hundreds of peoples have been reported in Kosovo and Bulgaria which were eventually linked with the water sources. Similarly, tens of human cases originated from the water sources have been reported in Georgia, Macedonia, and Norway (Kılıç et al. 2015; Hennebiquea et al. 2019).

\section{Geographical distribution}

Tularemia has been reported in many countries of the world since it was first reported in the USA. The incidence of tularemia has changed from 0.37 to 2.8/one million cases per year over the past 50 years in the USA. Although, a decrease is seen after the 1950s, it tended to emerge in 2015 and beyond in the USA (CDC 2018). F. tularensis subsp. tularensis is the most virulent subspecies which accounts for approximately $90 \%$ of human infections in North America (Șahin 2009; Grunow et al. 2012). Mostly, the American cases of tularemia in humans were reported during summer and fall seasons because its relation with arthropod acts like bites from infected ticks or flies. However, infections due to animal handling and hunting can occur at any time of the year. Canada is the other country where tularemia is endemic in North America (Table 1).

Tularemia is widely distributed throughout European countries. It can be said that it followed a fluctuant course between 1995 and 2017 (GIDEON 2019). The total number of confirmed cases per one hundred thousand people ranged from 0.1 to 0.06 between 2014 and 2018 (ECDC 2019). Especially, some of the Nordic countries (Finland and Sweden) are ascribed as endemic areas for tularemia. In these territories, tularemia is typically transmitted by mosquito bites. More recently, a tularemia outbreak, which is the biggest epidemic for more than 50 years, has been linked with mosquito bites in Sweden in 2019 (Dryselius et al. 2019). Tularemia is also occurring in Eastern Europe and Russia. Outbreaks in these regions increased after the Second World War. Kosovo reports the highest annual incidence of tularemia in Europe at a rate of 5.2 per 100,000 (Grunow et al. 2012). However, case number has not decreased lately in Kosovo (Sadiku et al. 2015; GIDEON 2018). Tularemia shows a seasonal pattern in these countries with relatively cold climates, with most cases occurring from July to November, which is consistent with a higher likelihood of exposure to the organism or vectors due to recreational outdoor activities. Albania, Greece, Iceland, UK, Ireland, and Liechtenstein are some of the European countries known as free from human tularemia (Table 1). Tularemia is occurring in parts of Asia. Cases have been reported in China and Japan, which represent the Eastern part of the Asia continent. Iran and Turkey are the members of Western Asia countries where human tularemia cases have been reported. The Caucasus nations, Armenia and Azerbaijan, are the other countries that regularly report cases. In certain countries, the ingestion of contaminated water is the main transmission route of the disease: one such example is Turkey. A majority of the cases have been reported from rural or semirural areas of Turkey (Ogden et al. 2014), mostly during late summer or early autumn season (Orkun et al. 2014). Kazakhstan, Uzbekistan, and Turkmenistan are the regions that tularemia has been reported in Central Asia (Table 1) (Olsufiev 1977; Oyston and Quarry 2005).

Currently, Africa and South America are considered free of tularemia. While some cases of the disease were reported from Sudan and Kenya, they need confirmation through standard methods. Recently, few reports have been made from Australia and these cases have been confirmed by culture method (Table 1). Kenya has an exceptional situation; due to the lack of reliable laboratory diagnostic facilities and the presumptive clinical management of diseases coursing with fever such as tularemia, it is likely to be misdiagnosed. However, the researchers may have unwillingly reported an acute infection in patients rather than a sole serosurvey. Namely, they have used an ELISA kit that allows detecting all classes of antibodies (one of these, IgM, represents the acute form of the disease) to the lipopolysaccharide of $F$. tularensis in human serum. Moreover, the patients tested have shown some common clinical presentations of tularemia such as lymphadenopathy, generalized body aches, malaise/ fatigue, and sore throat (Nejeru et al. 2017).

\section{Symptoms}

The incubation period of tularemia is usually from 3 to 5 days, but it can extend up to 14 days. The generalized symptoms of 
Table 1 The global distribution of tularemia

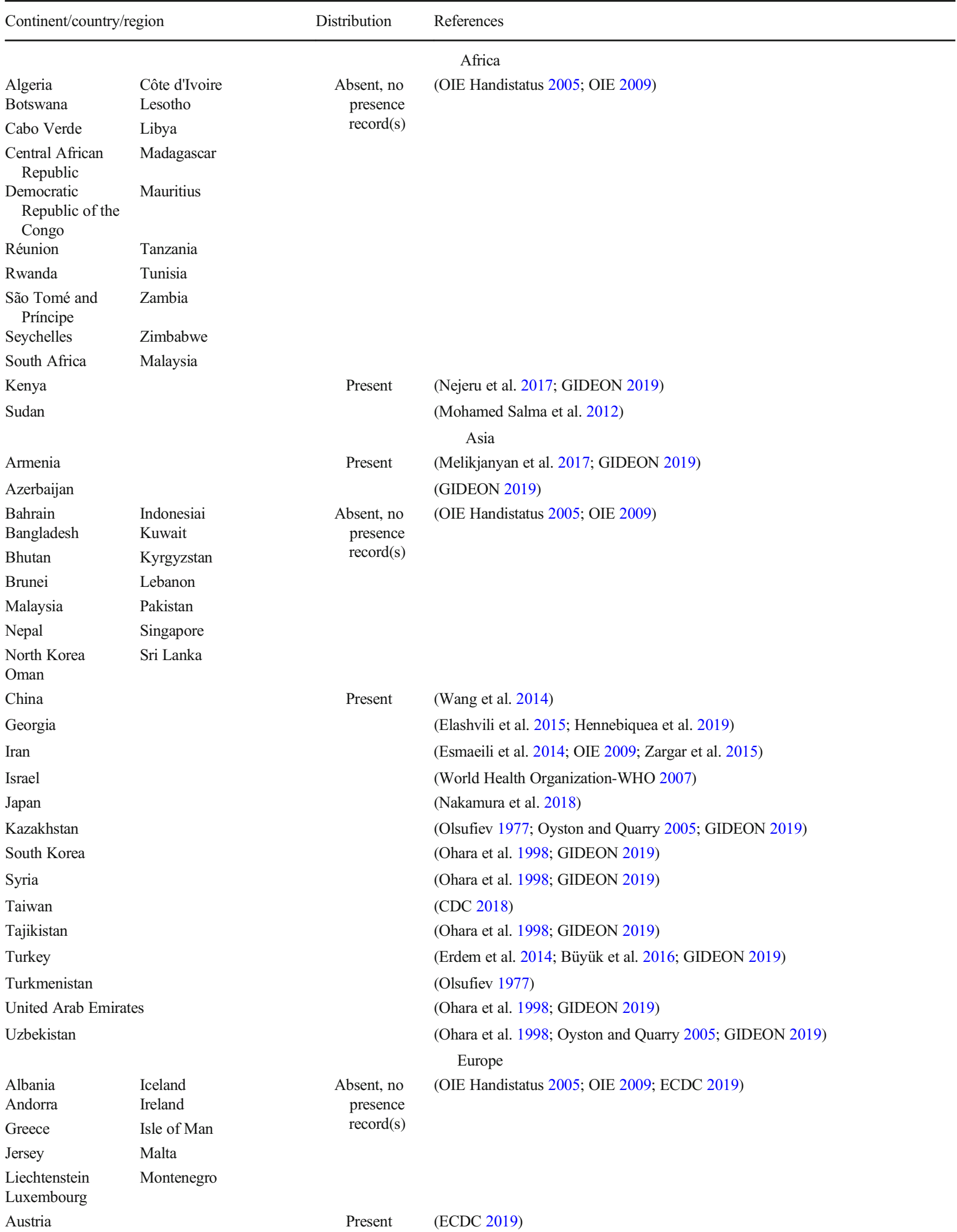


Table 1 (continued)

\begin{tabular}{|c|c|c|c|}
\hline \multicolumn{2}{|c|}{ Continent/country/region } & Distribution & References \\
\hline \multicolumn{3}{|l|}{ Belgium } & (ECDC 2019) \\
\hline \multicolumn{3}{|c|}{ Bosnia and Herzegovina } & (GIDEON 2019) \\
\hline \multicolumn{3}{|l|}{ Bulgaria } & $\begin{array}{l}\text { (OIE 2009; Padeshki et al. 2010; ECDC 2019; } \\
\text { GIDEON 2019) }\end{array}$ \\
\hline \multicolumn{3}{|l|}{ Croatia } & (OIE 2009; Gürcan 2014; ECDC 2019) \\
\hline \multicolumn{3}{|l|}{ Cyprus } & (Uncu et al. 2017) \\
\hline \multicolumn{3}{|l|}{ Czechia } & $\begin{array}{l}\text { (Hubálek and Halouzka 1997; OIE 2009; Gürcan 2014; } \\
\text { ECDC 2019) }\end{array}$ \\
\hline \multicolumn{3}{|l|}{ Denmark } & (Byström et al. 2005; Haulrig et al. 2020) \\
\hline \multicolumn{3}{|l|}{ Estonia } & (ECDC 2019) \\
\hline \multicolumn{3}{|l|}{ Finland } & (Syrjala et al. 1985; OIE 2009; Rossow et al. 2014; ECDC 2019) \\
\hline \multicolumn{3}{|l|}{ France } & (Decors et al. 2011; Maurin et al. 2011; ECDC 2019) \\
\hline \multicolumn{3}{|l|}{ Germany } & $\begin{array}{l}\text { (Kaysser et al. 2008; OIE 2009; Müller et al. 2013; Robert Koch Ins. } \\
\text { 2017; ECDC 2019) }\end{array}$ \\
\hline \multicolumn{3}{|l|}{ Hungary } & (OIE 2009; Gyuranecz et al. 2012; ECDC 2019) \\
\hline \multicolumn{3}{|l|}{ Italy } & (ECDC 2019) \\
\hline \multicolumn{3}{|l|}{ Latvia } & (ECDC 2019) \\
\hline \multicolumn{3}{|l|}{ Lithuania } & (ECDC 2019) \\
\hline \multicolumn{3}{|l|}{ Netherlands } & (ECDC 2019; GIDEON 2019) \\
\hline \multicolumn{3}{|l|}{ Macedonia } & (GIDEON 2019) \\
\hline \multicolumn{3}{|l|}{ Norway } & $\begin{array}{l}\text { (Berdal et al. 1996; OIE 2009; Nordstoga et al. 2014; ECDC 2019; } \\
\text { GIDEON 2019) }\end{array}$ \\
\hline \multicolumn{3}{|l|}{ Poland } & (OIE 2009; Moniuszko et al. 2011; ECDC 2019) \\
\hline \multicolumn{3}{|l|}{ Portugal } & (Lopes de Carvalho et al. 2018; ECDC 2019) \\
\hline \multicolumn{3}{|l|}{ Romania } & (ECDC 2019; GIDEON 2019) \\
\hline \multicolumn{3}{|l|}{ Russia } & (Sandström et al. 1992; Efimov et al. 2003; OIE 2009; GIDEON 2019) \\
\hline \multicolumn{3}{|l|}{ Serbia } & (GIDEON 2019) \\
\hline \multicolumn{3}{|l|}{ Slovakia } & (Guryčová et al. 2001; OIE 2009; Gürcan 2014; ECDC 2019) \\
\hline \multicolumn{3}{|l|}{ Slovenia } & $($ ECDC 2019) \\
\hline Spain & & & $\begin{array}{l}\text { (Anda et al. 2001; García del Blanco et al. 2004; OIE } \\
\text { 2009; ECDC 2019) }\end{array}$ \\
\hline Sweden & & & $\begin{array}{l}\text { (Mörner et al. 1988; OIE 2009; Rydén et al. 2011; Dryselius et al. } \\
\text { 2019; GIDEON 2019) }\end{array}$ \\
\hline Switzerland & & & (Friedl et al. 2005; OIE 2009) \\
\hline Ukraine & & & (GIDEON 2019) \\
\hline UK & & & (ECDC 2019) \\
\hline & & & North America \\
\hline Barbados & Cuba & Absent, no & (OIE Handistatus 2005; OIE 2009) \\
\hline Bermuda & Curaçao & presence & \\
\hline $\begin{array}{l}\text { British Virgin } \\
\text { Islands }\end{array}$ & Dominica & record(s) & \\
\hline Cayman Islands & Dominican Republic & & \\
\hline Costa Rica & El Salvador & & \\
\hline Greenland & Nicaragua & & \\
\hline Guatemala & Panama & & \\
\hline Haiti & Saint Kitts and Nevis & & \\
\hline Honduras & $\begin{array}{l}\text { Saint Vincent and the } \\
\text { Grenadines }\end{array}$ & & \\
\hline Mexico & Trinidad and Tobago & & \\
\hline Canada & & Present & \\
\hline
\end{tabular}


Table 1 (continued)

\begin{tabular}{|c|c|c|c|c|}
\hline \multicolumn{3}{|c|}{ Continent/country/region } & Distribution & References \\
\hline & & & \multirow{17}{*}{ Present } & (OIE 2009; Wobeser et al. 2009; Blackburn et al. 2013; GIDEON 2019) \\
\hline $\begin{array}{l}\text { USA } \\
\text { - Alabama }\end{array}$ & - Colorado & - Illinois & & \multirow{15}{*}{$\begin{array}{l}\text { (Geiger 1931; Jellison et al. 1965; Evans et al. 1985; Magee et al. 1989; Taylor } \\
\text { et al. 1991; Gliatto et al. 1994; Shoemaker et al. 1997; Lindley et al. 2002; } \\
\text { Avashia et al. 2004; Magnarelli et al. 2007; O’Toole et al. 2008; Sinclair et al. } \\
\text { 2008; OIE 2009; Calanan et al. 2010; Scheftel et al. 2010; } \\
\text { Hansen et al. 2011; Brett et al. 2014; Larson et al. 2014; CDC 2018; } \\
\text { GIDEON 2019) }\end{array}$} \\
\hline - Alaska & $\begin{array}{l}\text { Connect- } \\
\text { icut }\end{array}$ & - Indiana & & \\
\hline - Arizona & - Delaware & - Iowa & & \\
\hline - Arkansas & - Florida & - Kansas & & \\
\hline - California & - Idaho & - Kentucky & & \\
\hline - Louisiana & - Missouri & $\begin{array}{l}\text { - New } \\
\text { Jersey }\end{array}$ & & \\
\hline - Maryland & - Montana & $\begin{array}{l}- \text { New } \\
\quad \text { Mexico }\end{array}$ & & \\
\hline - Massachusetts & - Nebraska & - New York & & \\
\hline - Michigan & - Nevada & $\begin{array}{l}\text { - North } \\
\text { Carolina }\end{array}$ & & \\
\hline - Minnesota & $\begin{array}{l}\text { - New } \\
\quad \text { Hampsh- } \\
\text { ire }\end{array}$ & $\begin{array}{l}\text { - North } \\
\text { Dakota }\end{array}$ & & \\
\hline - Ohio & $\begin{array}{l}\text { - South } \\
\text { Dakota }\end{array}$ & - Virginia & & \\
\hline - Oklahoma & - Tennessee & $\begin{array}{l}\text { Washin- } \\
\text { gton }\end{array}$ & & \\
\hline - Oregon & - Texas & $\begin{array}{l}\text { - West } \\
\text { Virginia }\end{array}$ & & \\
\hline - Pennsylvania & - Utah & - Wisconsin & & \\
\hline - South Carolina & - Vermont & - Wyoming & & \\
\hline \multicolumn{4}{|c|}{ Oceania } & \\
\hline $\begin{array}{l}\text { Australia } \\
\text {-Northern Territory }\end{array}$ & & & Present & $\begin{array}{l}\text { (Whipp et al. 2003; OIE 2009; Siddaramappa et al. } \\
\text { 2011; Jackson et al. 2012) }\end{array}$ \\
\hline \multicolumn{5}{|l|}{-Tasmania } \\
\hline \multirow[t]{2}{*}{$\begin{array}{l}\text { French Polynesia } \\
\text { New Caledonia } \\
\text { New Zealand }\end{array}$} & $\begin{array}{l}\text { Samoa } \\
\text { Vanuatu }\end{array}$ & & $\begin{array}{r}\text { Absent, No } \\
\text { presence } \\
\text { record(s) }\end{array}$ & $\begin{array}{l}\text { (OIE Handistatus } \\
\text { 2005; OIE 2009) }\end{array}$ \\
\hline & & & & South America \\
\hline $\begin{array}{l}\text { Argentina } \\
\text { Bolivia }\end{array}$ & $\begin{array}{l}\text { Chile } \\
\text { Colombia }\end{array}$ & & $\begin{array}{r}\text { Absent, no } \\
\text { presence }\end{array}$ & (OIE Handistatus 2005; OIE 2009) \\
\hline Brazil & Ecuador & & record(s) & \\
\hline Falkland Islands & Peru & & & \\
\hline Guyana & Uruguay & & & \\
\hline Paraguay & Venezuela & & & \\
\hline
\end{tabular}

tularemia include fever along with malaise, chills, and headache. However, tularemia has six classical forms in humans, including ulcero-glandular, glandular, pneumonic, oro-pharyngeal, oculoglandular, and systemic. Mostly, the site and route of infection determine the clinical form of the disease. Infection through ingestion of the bacterium typically results in the oro-pharyngeal form of the disease and symptoms such as pharyngitis, fever, and cervical lymphadenitis appear (Penn 1994). Infection by direct contact with an infected animal or a vector bite results in the ulcero-glandular form of tularemia having symptoms of skin lesions and lymphadenopathy. Although the glandular tularemia resembles the ulceroglandular form in terms of transmission, it differs with the presence of regional lymphadenopathy without any detectable skin lesion. The oculo-glandular form often develops through contact of contaminated hands, a splash of infected animal's body fluids into the conjunctiva, or direct contact 
with contaminated water. The pneumonic form develops as the result of the inhalation of infectious aerosols. Moreover, pneumonic form and typhoidal forms of tularemia are considered systemic forms as they develop by the spread of bacteria through blood circulation as a systemic disease. The systemic forms (pneumonic and typhoidal) of the most virulent type A.I strain of tularemia have a high mortality rate (up to 60\%) in the USA (Plourde et al. 1992). Only generalized signs have been reported in cases of the typhoidal form of the disease. Besides these wellcharacterized clinical forms, tularemia can also cause secondary pleuropneumonia, meningitis, and sepsis, which can lead to shock and death in humans (AVMA 2003).

\section{Diagnosis}

The diagnosis of tularemia mostly relies on positive serology in combination with clinical and epidemiological contexts. Tularemia is suspected when fever along with lymphadenopathy is reported in a patient, especially with a history of contact with animals, e.g., rabbit, deer, or ticks. However, its differential diagnosis from $\mathrm{Q}$ fever, plague, and psittacosis is required. Microagglutination test or ELISA (Grunow et al. 2000; Büyük et al. 2016) can detect serum antibodies against $F$. tularensis. However, the cross-reactivity has been reported with Salmonella, Brucella, Legionella, and Yersinia spp. (Karataş Yeni and İzgür 2015a). It is supposed that a 4-fold rise in anti-Francisella serum antibody titer within 2-4 weeks confirms the presence of tularemia infection (Karataş Yeni and İzgür 2015b).

Francisella tularensis is a biohazardous pathogen; therefore, specially equipped laboratories and skilled laboratory personnel are required for culture and diagnosis of tularemia. Isolation of the bacteria should be done in Biosafety Level 3 laboratories (ASM 2016). Therefore, the diagnosis of the pathogen through culture methods is difficult and not common $(\leq 10 \%)$. Microbiological techniques include culturing of the causative organism from the samples. Being a strict aerobe, $F$. tularensis requires a special medium with supplementation of sulfhydryl compounds for its optimal growth. It requires cysteine-enriched media, e.g., cysteine heart agar with red blood cells or cysteine glucose blood agar. Gray colonies having 4-mm diameter are reported on glucose cysteine blood agar along with the color change of the medium to green. Colony morphology may vary with strains. The best incubation temperature for its optimal growth is $35^{\circ} \mathrm{C}$. Moreover, colonies appear in 2 to 4 days of incubation. Mouse inoculation test can also be performed which results in the death of experimental mice. Fluorescent antibody staining of exudate or cultured bacteria enhances the detection sensitivity of direct smears.

Polymerase chain reaction (PCR)-based methods are useful when tissue samples are available. Presence of the $F$. tularensis in infected tissues can be confirmed by amplification of target sequences of nucleic acids using specific primers (Forsman et al. 1994; Keim et al. 2007). A new technique, MALDI-ToF mass spectrometry, is recently evaluated as a useful tool for rapid identification and typing of the isolated $F$. tularensis strains. Accuracy of this analysis highly depends on available mass spectrum databases. However, MALDI-ToF MS-analysis provides results in accordance with the PCR assay (Afanas'ev et al. 2015; Karatuna et al. 2016).

\section{Treatment}

Antimicrobial therapy should be applied to prevent complications in F. tularensis infections, to shorten the recovery period and to decrease mortality. Aminoglycosides, tetracyclines, quinolones, and chloramphenicol are frequently used in the treatment of tularemia (Tärnvik and Chu 2007; Sjöstedt 2016). Resistance against penicillins, cephalosporins, carbapenems, macrolides, and clindamycin has been reported (Kılıç and Yeşilyurt 2011; Origgi et al. 2014). Moreover, higher relapse rates are also reported after antimicrobial therapy. So, aminoglycosides are usually administered for 10 days, fluoroquinolones for 14 days, and doxycycline for 21 days to avoid the relapse (Caspar and Maurin 2017).

The treatment approach depends on the severity of the infection. For example, in severe infection, such as prolonged or extensive systemic symptoms, sepsis with or without renal failure, typhoidal tularemia, and symptomatic pneumonic tularemia, the aminoglycosides (gentamycin and streptomycin) are the drugs of the first choice (Enderlin et al. 1994; Johansson et al. 2002). Successful outcomes have been reported in the use of aminoglycosides in the treatment of complications of tularemia such as meningitis and endocarditis with the combination of tetracycline, chloramphenicol, and ciprofloxacin (Barbaz et al. 2013). Gentamicin is the preferred aminoglycoside for the treatment of tularemia in children; however, streptomycin is used to eliminate the gentamicin failures (Kaya et al. 2011). Ciprofloxacin and doxycycline are recommended drugs for mild or moderate infection in adults. These two drugs and chloramphenicol combined with an aminoglycoside can be used for the management of meningitis and endocarditis (Barbaz et al. 2013). Azithromycin represents a first-line treatment option for tularemia during pregnancy by overcoming the side effects of gentamicin and ciprofloxacin (Dentan et al. 2013; Johnsrud et al. 2019). The treatment of immunosuppressed patients with tularemia is proven with the use of gentamicin, a fluoroquinolone, or doxycycline, alone or in combination (Ozkok et al. 2012; Alias et al. 2017).

The duration of treatment for tularemia ranges 10 to 14 days. However, the duration of the treatment can be shortened in cases in children to 7 days or extended to 21 days in cases of meningitis and endocarditis (Gaci et al. 2017). The post-exposure prophylaxis differs between adults and children. This depends on the 
type of exposure and the length of time since the exposure. Regimens for adults are oral ciprofloxacin $(500 \mathrm{mg}$ ) or doxycycline $(100 \mathrm{mg})$, each twice daily for 14 days. The recommended doses for children are ciprofloxacin $(15 \mathrm{mg} / \mathrm{kg}$ ) orally twice daily or doxycycline $(2.2 \mathrm{mg} / \mathrm{kg}$ ) orally twice daily (for those $<45 \mathrm{~kg}$ ), and $100 \mathrm{mg}$ orally twice daily (for those $\geq 45 \mathrm{~kg}$ ) (Dennis et al. 2001).

\section{Prevention}

Individuals can easily protect themselves by adapting the following precautionary measures that would minimize the risk of exposure to the organism (Sjöstedt 2007a; WHO 2007).

1. Avoid drinking, bathing, swimming, or working in untreated water where infection may be common among wild animals.

2. Use impervious gloves and clothes when skinning, handling, or dressing wild animals, especially rabbits.

3. Cook the meat of wild rabbits and rodents thoroughly.

4. Use insect repellents.

5. Protect food warehouses from contact with vector animals.

6. Wear protective masks against infected dust and aerosols if you are a member of the professional group, such as farmers or gardeners.

7. Avoid being bitten by deer flies and ticks.

8. Check your clothing often for ticks climbing toward open skin. Wear white or light-colored long-sleeved shirts and long pants so the tiny ticks are easier to see. Tuck long pants into your socks and boots. Wear a head covering or hat for added protection.

9. Walk in the center of trails so weeds do not brush against you.

10. If you let your pets outdoors, check them often for ticks. Infected ticks can also transmit tick-borne diseases to them. Check with your veterinarian about preventive measures against tick-borne diseases. You are also at risk from ticks that "hitch a ride" on your pets but fall off in your home.

11. Make sure the property around your home is unattractive to ticks. Keep your grass mowed and keep weeds cut.

12. The person or veterinarian working in close contact with the rabbits or suspected animals should be vaccinated against the pathogen.

\section{Vaccines against tularemia}

Currently, no vaccine against tularemia is available or approved for humans. However, efforts have been done to develop vaccines (killed and attenuated) against tularemia. Killed in this manner, live attenuated and subunit vaccine candidates were evaluated in several countries. Apart from an effective attenuated vaccine that was lost unintentionally (Tigertt 1962), other vaccines have not yielded promising results for protective immunity (Titball and Sjostedt 2003; Conlan 2004; Valentino et al. 2009). At the end of all these studies, it was suggested that different requirements for protective vaccines against each subtype of $F$. tularensis are required and the attenuation and protective ability of a vaccine should be adjusted in a delicate balance (Barry et al. 2009). Furthermore, due to the intracellular adaptation of $F$. tularensis, the new vaccine development initiatives should aim to provide outstanding cell-mediated immunity for longterm protection (Sjöstedt 2007a).

\section{An agent of biological warfare}

Having low infectious dose and easy dissemination of the agent high aerosol-related infection rate and ability to induce fatal disease makes $F$. tularensis a potential agent of biological warfare. The US Department of Health and Human Services classified it as a List A select agent of the highest concern of bioterrorism use. Indeed, there were some certain reports about the use of $F$. tularensis as a biological weapon by Japan, Russia, and Germany during World War II (Dennis et al. 2001).

The Former Soviet Union developed the drug-resistant F. tularensis, weaponized, and stockpiled it until the 1960s. World Health Organization warned about the deaths of 19,000 persons in case of use of $F$. tularensis as a biological weapon in a city having a population of 5 million people (Christopher et al. 1997). Centers for Disease Control and Prevention (CDC) estimated a treatment cost of about 5.4 billion US dollar for every 100,000 persons exposed to the agent (Dennis et al. 2001). In case of an attack of a biological weapon having $F$. tularensis, important factors to minimize the losses are the ability to make a rapid diagnosis, its differentiation from environmental strains, and availability of effective drugs or vaccines.

\section{Future perspectives}

The countries having natural conditions favorable for tickborne infections in animals and humans need to develop a disease management strategy and establish control programs against tick-borne diseases (TBDs). Moreover, we should also consider the movements of animals (as a result of migration/ trade/games) having $F$. tularensis infection as a concerning risk of zoonoses. The European Centre for Disease Prevention and Control (ECDC 2019) advised to devise and 
adopt the strategy of "One Health Initiative" or "One Medicine Perspective." This strategy should be based on the knowledge of the host, pathogen, tick disease triangle in relation with global warming, environmental changes, socioeconomic status of affected human societies, and the ecology of tick habitats and tick distributions. To break this triangle, an integrated tick control program is required throughout the disease-endemic regions. Recombinant anti-tick vaccines can be used as an advanced tick control technique especially in the case of animals. Another important approach is to promote disease-resistant animals instead of susceptible breeds and application of immunization programs.

According to the One Health concept, research projects for the control of TBDs should be a top priority area. On the other hand, the impact of climate change, urbanization, industrial, and agricultural pollution should be considered for their possible effect on infectious diseases. It is also suggested to implement a regional disease control program utilizing the One Health Concept to combat infectious diseases (ECDC 2019).

\section{Conclusion}

It is concluded that a major feature of tularemia is the variety of sources and modes of human infections acquired by handling or consumption of infected animal materials, vector bites, contact with aquatic environment, and inhalation of aerosols. The environmental conditions to which the bacterium has adapted may deviate greatly from that of another location and other environmental conditions. Thus, tularemia has been figuratively described as a chameleon with many faces that adapts to various environmental conditions. The climates of certain regions are suitable for tularemia infections in animals and humans. The presence of suitable tick habitats and prevalence of the pathogen make the environment favorable for the spread of this disease. Moreover, migratory birds are also a constant threat for the spread of new infections in some countries. Therefore, countries need their own disease management system for the control of infectious diseases. Awareness should also be given to the public to adopt precautionary measures for control of tularemia by One Health concept. Experts should design and implement advanced research projects for the control of tularemia through the development of safe, effective vaccines and anti-Francisella drugs should be a high-priority research area.

Acknowledgments We thank Dr. Anders Sjöstedt from the Department of Clinical Bacteriology, Infection and Immunology, Umeå University, for his guidance through the systematic review approach.

\section{Compliance with ethical standards}

Conflict of interest The authors declare that they have no conflict of interest.

\section{References}

Afanas'ev MV, Mironova LV, Balakhonov SV (2015) MALDI-ToF massspectrometric analysis for the identification of plague, cholera, and tularemia causative agents. MolGenet Microbiol Virol 30:5763. https://doi.org/10.3103/S0891416815020020

Alias T, Fallahzadeh MK, Berhe M (2017) Tularemia presenting as pulmonary nodules in an immunocompromised patient. Proc (Bayl Univ Med Cent) 30:175-176. https://doi.org/10.1080/08998280.2017. 11929573

American Society for Microbiology (2016) Sentinel level clinical laboratory guidelines for suspected agents of bioterrorism and emerging infectious diseases: Francisella tularensis. https://www.asm.org/ images/PSAB/LRN/Tularemia316.pdf

American Veterinary Medical Association (2003) Tularemia facts. https://www.avma.org/tularemia-facts

Anda P, Segura del Pozo J, Díaz García JM, Escudero R, García Peña FJ, López Velasco MC, Martínez Navarro F (2001) Waterborne outbreak of tularemia associated with crayfish fishing. Emerg Infect Dis 7:575-582. https://doi.org/10.3201/eid0707.010740

Anda P, Pearson A, Tärnvik A (2007) WHO guidelines on tularemia, clinical expression in humans.https://www.who.int/csr/resources/ publications/WHO_CDS_EPR_2007_7.pdf?ua=1

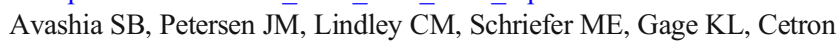
M, Kool JL (2004) First reported prairie dog-to-human tularemia transmission, Texas, 2002. Emerg Infect Dis 10:483-486. https:// doi.org/10.3201/eid1003.030695

Barbaz M, Piau C, Tadie JM, Pelloux I, Kayal S, Tattevin P, Le Tulzo Y (2013) Rhombencephalitis caused by Francisella tularensis. J Clin Microbiol 51:3454-3455. https://doi.org/10.1128/JCM.01018-13

Barry EM, Cole L, Santiago AE (2009) Vaccines against tularemia. Human Vaccines 5(12):832-838. https://doi.org/10.4161/hv.10297

Belding DL, Merrill B (1941) Tularemia in imported rabbits in Massachusetts. N Engl J Med 224:1085-1087

Bell JF, Stewart SJ (1975) Chronic shedding tularemia nephritis in rodents: possible relation to occurrence of Francisella tularensis in lotic waters. J Wildl Dis 11:421-430. https://doi.org/10.7589/ 0090-3558-11.3.421

Berdal BP, Mehl R, Meidell NK, Lorentzen-Styr AM, Scheel O (1996) Field investigations of tularemia in Norway. FEMS Immunol Med Microbiol 13:191-195. https://doi.org/10.1111/j.1574-695X.1996.tb00235.x

Blackburn J, Tremblay É, Tsimiklis C, Thivierge B, Lavergne V (2013) Overwhelming sepsis after a cat bite. Can J Infect Dis Med Microbiol 24:31-32. https://doi.org/10.1155/2013/248397

Brett ME, Respicio-Kingry LB, Yendell S, Ratard R, Hand J, Balsamo G, Mead P (2014) Outbreak of Francisella novicida bacteremia among inmates at a Louisiana correctional facility. Clin Infect Dis 59:826833. https://doi.org/10.1093/cid/ciu430

Büyük F, Çelebi Ö, Çelik E, Çelebi B, Kiliç S, Gülmez Sağlam A, Şahin M (2016) The prevalence of tularemia in occupational groups that have contact with animals. Turkish J Med Sci 46:451-456. https:// doi.org/10.3906/sag-1412-138

Byström M, Böcher S, Magnusson A, Prag J, Johansson A (2005) Tularemia in Denmark: identification of a Francisella tularensis subsp. holarctica strain by real-time PCR and high-resolution typing by multiple-locus variable-number tandem repeat analysis. J Clin Microbiol 43:5355-5358. https://doi.org/10.1128/JCM.43.10. 5355-5358.2005

Calanan RM, Rolfs RT, Summers J, Coombs J, Amadio J, Holbrook J, Mead P (2010) Tularemia outbreak associated with outdoor exposure along the western side of Utah Lake, Utah, 2007. Public Health Rep 125:870-876. https://doi.org/10.1177/003335491012500614

Carvalho CL, Lopes de Carvalho I, Zé-Zé L, Núncio MS, Duarte EL (2014) Tularaemia: a challenging zoonosis. Comp Immunol Microbiol Infect Dis 37:85-96. https://doi.org/10.1016/j.cimid.2014.01.002 
Caspar Y, Maurin M (2017) Francisella tularensis susceptibility to antibiotics: a comprehensive review of the data obtained in vitro and in animal models. Front Cell Infect Microbiol 7(122):1-18. https://doi. org/10.3389/fcimb.2017.00122

Centers for Disease Control and Prevention (2018) Tularemia. https:// www.cdc.gov/tularemia/statistics/index.html

Christopher GW, Cieslak TJ, Pavlin JA, Eitzen Jr EM (1997) Biological warfare. A historical perspective. J Am Med Assoc 278:412-417

Conlan JW (2004) Vaccines against Francisella tularensis - past, present and future. Expert Rev Vaccines 3:307-314. https://doi.org/10. 1586/14760584.3.3.307

Decors A, Lesage C, Jourdain E, Giroud P, Houbron P, Vanhem P, Madani N (2011) Outbreak of Tularaemia in brown hares (Lepus europaeus) in France. Euro Surveill 16:28

Dennis DT, Inglesby TV, Henderson DA, Bartlett JG, Ascher MS, Eitzen E, Tonat K (2001) Tularemia as a biological weapon: medical and public health management. J Am Med Assoc 285:2763-2773. https://doi.org/10.1001/jama.285.21.2763

Dentan C, Pavese P, Pelloux I, Boisset S, Brion J, Stahl J, Maurin M (2013) Treatment of tularemia in pregnant woman, France. Emerg Infect Dis 19(6):996-998. https://doi.org/10.3201/eid1906.130138

Dryselius R, Hjertqvist M, Mäkitalo S, Lindblom A, Lilja T, Eklöf D, Lindström A (2019) Large outbreak of tularaemia, central Sweden, July to September 2019. Euro Surveill 24:1900603. https://doi.org/ 10.2807/1560-7917.ES.2019.24.42.1900603

Efimov VM, Galaktionov Y, Galaktionova TA (2003) Reconstruction and prognosis of water vole population dynamics on the basis of tularemia morbidity among Novosibirsk oblast residents. Dokl Biol Sci 388:59-61. https://doi.org/10.1023/a:1022456212332

Ehrensperger F, Riederer L, Friedl A (2018) Tularemia in a jogger woman after the attack by a common buzzard (Buteo buteo): a "one health" case report. Schweiz Arch Tierheilkd 160(3):185-188. (Article in French, German). https://doi.org/10.17236/sat00153

Elashvili E, Kracalik I, Burjanadze I, Datukishvili S, Chanturia G, Tsertsvadze N, Beridze L, Shavishvili M, Dzneladze A, Grdzelidze M, Imnadze P, Pearson A, Blackburn JK (2015) Environmental monitoring and surveillance of rodents and vectors for Francisellatularensis following outbreaks of human tularemia in Georgia. Vector Borne Zoonotic Dis 15:633-636. https://doi.org/10.1089/vbz.2015.1781

Eliasson H, Lindback J, Nuorti JP, Arneborn M, Giesecke J, Tegneli A (2002) The 2000 tularemia outbreak: a case control study of risk factors in disease-endemic and emergent areas, Sweden. Emerg Infect Dis 9:956-960

Eliasson H, Broman T, Forsman M, Back E (2006) Tularemia: current epidemiology and disease management. Infect Dis Clin N Am 20: 289-311. https://doi.org/10.3201/eid0809.020051

Ellis J, Oyston P, Green M, Titball R (2002) Tularemia. Clin Microbiol 15:631-646. https://doi.org/10.1128/CMR.15.4.631-646.2002

Enderlin G, Morales L, Jacobs RF, Cross JT (1994) Streptomycin and alternative agents for the treatment of tularemia: review of the literature. Clin Infect Dis 19(1):42-47. https://doi.org/10.1093/clinids/19.1.42

Erdem H, Ozturk ED, Yesilyurt M, Karabay O, Elaldi N, Celebi G, Agalar C (2014) Evaluation of Tularaemia courses: a multicentre study from Turkey. Clin Microbiol Infect 20(12):O1042-O1051. https://doi.org/10.1111/1469-0691.12741

Esmaeili S, Gooya MM, Shirzadi MR, Esfandiari B, Amiria FB, Behzadi MY, Banafshi O, Mostafavi E (2014) Seroepidemiological survey of tularemia among different groups in western Iran. Int J Infect Dis 18:27-31. https://doi.org/10.1016/j.ijid.2013.08.013

European Centres for Disease Control and Prevention (2019) Tularaemia Annual Epidemiological Report for 2018. https://www.ecdc.europa. eu/en/publications-data/tularaemia-annual-epidemiological-report-2018

Evans ME, Gregory DW, Schaffner W, McGee ZA (1985) Tularemia: a 30-year experience with 88 cases. 64:251-269

Forsman M, Sandström G, Sjostedt A (1994) Analysis of 16S ribosomal DNA sequences of Francisella strains and utilization for determination of the phylogeny of the genus and for identification of strains by PCR. Int J Syst Bacteriol 44:38-46

Friedl A, Heinzer I, Fankhauser H (2005) Tularemia after a dormouse bite in Switzerland. Eur J Clin Microbiol Infect Dis 24:352-354. https:// doi.org/10.1007/s10096-005-1322-x

Gaci R, Alauzet C, Selton-Suty C, Lozniewski A, Pulcini C, May T, Goehringer F (2017) Francisella tularensis endocarditis: two case reports and a literature review. Infect Dis (Lond) 49:128-131. https://doi.org/10.1080/23744235.2016.1222546

García del Blanco N, Gutiérrez CB, De la Puente VA, Rodríguez Ferri EF (2004) Biochemical characterisation of Francisella tularensis strains isolated in Spain. Vet Rec 154:55-56. https://doi.org/10. $1128 / \mathrm{jcm} .40 .8 .2964-2972.2002$

Geiger JC (1931) Tularemia in cattle and sheep. Calif West Med 34:1-3 GIDEON (2018) Tularemia: global status: Los Angeles. California, GIDEON Informatics https://www.gideononline.com/2018/08/22/ update-august-22-2018

GIDEON (2019) Infectious diseases of the world. GIDEON Informatics, Los Angeles, California,GIDEONInformatics.https://www. gideononline.com/ebooks/country/infectious-diseases-of-the-world/

Gliatto JM, Rae JF, McDonough PL, Dasbach JJ (1994) Feline tularemia on Nantucket Island, Massachusetts. J Vet Diagn Investig 6:102-105

Grunow R, Splettstoesser W, McDonald S, Otterbein C, O'Brien T, Morgan C, Aldrich J, Hofer E, Finke EJ, Meyer H (2000) Detection of Francisella tularensis in biological specimens using a capture enzyme-linked immunosorbent assay, an immunochromatographic handheld assay, and a PCR. Clin Diagn Lab Immunol 7:86-90. https://doi.org/10.1128/cdli.7.1.86-90.2000

Grunow R, Kalaveshi A, Kühn A, Mulliqi-Osmani G, Ramadani N (2012) Surveillance of Tularaemia in Kosovo, 2001 to 2010. Euro Surveill 17:20217. https://doi.org/10.2807/ese.17.28.20217-en

Gürcan Ș (2014) Epidemiology of tularemia. Balkan Med J 31:3-10. https://doi.org/10.5152/balkanmedj.2014.13117

Gurycova D, Kocianova E, Vyrostekova V, Rehacek J (1995) Prevalence of ticks infected with Francisella tularensis in natural foci of tularemia in western Slovakia. Eur J Epidemiol 11:469-474

Gurycová D, Výrosteková V, Khanakah G, Kocianová E, Stanek G (2001) Importance of surveillance of tularemia natural foci in the knownendemic area of Central Europe, 1991-1997. Wien Klin Wochenschr 113:433-438

Gyuranecz M, Reiczigel J, Krisztalovics K, Monse L, Szabóné GK, Szilágyi A, Erdélyi K (2012) Factors influencing emergence of tularemia, Hungary 1984-2010. Emerg Infect Dis 8:1379-1381. https://doi.org/10.3201/eid1808.111826

Hansen CM, Vogler AJ, Keim P, Wagner DM, Hueffer K (2011) Tularemia in Alaska, 1938-2010. Acta Vet Scand 53(61):1-7

Haulrig MB, Mathiasen G, Nielsen RM, Kromann CB, Krogfelt KA, Wiese L (2020) Two cases of tick-borne transmitted tularemia on southern Zealand, Denmark. APMIS 128:61-64. https://doi.org/10. 1111/apm. 13008

Hennebiquea A, Boisset S, Maurin M (2019) Tularemia as a waterborne disease: a review. Emerg Microbes Infect 8:1027-1042. https://doi. org/10.1080/22221751.2019.1638734

Hopla CE (1974) The ecology of tularemia. Adv Vet Sci Comp Med 18:25-53

Hopla CE, Hopla AK (1994) Tularemia. In: Steele JH et al (eds) CRC handbook of zoonoses. Section a: bacterial, rickettsial and mycotic diseases, vol 2, 2nd edn. CRC Press Inc, Boca Raton, Florida, pp $113-125$

Hubálek Z, Halouzka J (1997) Mosquitoes (Diptera: Culicidae), in contrast to ticks (Acari: Ixodidae), do not carry Francisella tularensis in a natural focus of tularemia in the Czech Republic. J Med Entomol 34:660-663. https://doi.org/10.1093/jmedent/34.6.660

Hubalek Z, Treml F, Halouzka J, Juricova Z, Hunady M, Janik V (1996) Frequent isolation of Francisella tularensis from Dermacentor reticulatus ticks in an enzootic focus of tularemia. Med Vet Entomol 10:241-246. https://doi.org/10.1111/j.1365-2915.1996.tb00737.x 
Hubalek Z, Sixl W, Halouzka J (1998) Francisella tularensis in Dermacentor reticulatus ticks from the Czech Republic and Austria. Wien Klin Wochenschr 110:909-910

Jackson J, McGregor A, Coole L, Ng J, Brown M, Ong CW, Sintchenko V (2012) Francisella tularensis subspecies holarctica, Tasmania, Australia. Emerg Infect Dis 18:1484-1486. https://doi.org/10. 3201/eid1809.111856

Jellison WL, Owen C, Bell JF, Kohls GM (1965) Tularemia and animal populations. Wildl Dis 17:1-22

Johansson A, Urich SK, Chu MC, Sjöstedt A, Tärnvik A (2002) In vitro susceptibility to quinolones of Francisella tularensis subspecies tularensis. Scand J Infect Dis 34:327-330. https://doi.org/10.1080/ 00365540110080773

Johansson A, Farlow J, Larsson P, Dukerich M, Chambers E, Byström M, Fox J, Chu M, Forsman M, Sjöstedt A, Keim P (2004) Worldwide genetic relationships among Francisella tularensis isolates determined by multiple-locus variable-number tandem repeat analysis. J Bacteriol 186:5808-5818. https://doi.org/10.1128/JB. 186.17.5808-5818.2004

Johnsrud JJ, Smith CR, Bradsher RW (2019) Serendipitous treatment of tularemia in pregnancy. Open Forum Infect Dis 6(10):ofz413. https://doi.org/10.1093/ofid/ofz413

Karataş Yeni D, İzgür M (2015a) Determination of the cross reaction of tularemia titer and Brucella on sheep at specific disease focus in Turkey. Etlik Vet Mikrobiyol Derg 26:7-10

Karataș Yeni D, İzgür M (2015b) Investigation on tularemia in potential reservoirs' of Anatolia. Vet J Ankara Univ 62:93-98

Karatuna O, Çelebi B, Can S, Akyar I, Kiliç S (2016) The use of matrixassisted laser desorption ionization-time of flight mass spectrometry in the identification of Francisellatularensis. Bosn J Basic Med Sci 16(2):132-138. https://doi.org/10.17305/bjbms.2016.894

Karpoff SP, Antonoff NI (1936) The spread of tularemia through water, as a new factor in its epidemiology. J Bacteriol 32:243-258

Kaya A, Uysal IO, Guven AS, Engin A, Gulturk A, Icagasioglu FD, Cevit $\mathrm{O}$ (2011) Treatment failure of gentamicin in pediatric patients with oropharyngeal tularemia. Med Sci Monit 17:CR376-CR380. https://doi.org/10.12659/MSM.881848

Kaysser P, Seibold E, Matz-Rensing K, Pfeffer M et al (2008) Reemergence of tularemia in Germany: presence of Francisella tularensis in different rodent species in endemic areas. BMC Infect Dis 8:157. https://doi.org/10.1186/1471-2334-8-157

Keim P, Johansson A, Wagner D (2007) Molecular epidemiology, evolution, and ecology of Francisella. Ann N Y Acad Sci 1105:30-66. https://doi.org/10.1196/annals.1409.011

Kılıc̣ S, Yeșilyurt M (2011) Tularemi: Güncel tedavi seçeneklerine genel bir bakıș. Klimik Derg 24:2-10. https://doi.org/10.5152/kd.2011.02

Kılıç S, Birdsell DN, Karagöz A, Çelebi B, Bakkaloglu Z, Arikan M et al (2015) Water as source of Francisella tularensis infection in humans, Turkey. Emerg Infect Dis 21:2213-2216. https://doi.org/ 10.3201/eid2112.150634

Larson MA, Fey PD, Hinrichs SH, Iwen PC (2014) Francisella tularensis bacteria associated with feline tularemia in the United States. Emerg Infect Dis 20:2068-2071. https://doi.org/10.3201/eid2012.131101

Lindley C, Avashia S, Hendricks K, Rawlings J et al (2002) Outbreak of tularemia among commercially distributed prairie dogs, 2002. Morb Mortal Wkly Rep 51:688-699

Lopes de Carvalho I, Nascimento P, Núncio MS, Toscano Rico M (2018) First case of tularemia reported in Portugal: probably of imported origin. Front Public Health 6:325. https://doi.org/10.3389/fpubh.2018.00325

Magee JS, Steele RW, Kelly NR, Jacobs RF (1989) Tularemia transmitted by a squirrel bite. Pediatr Infect Dis J 8:123-125

Magnarelli L, Levy S, Koski R (2007) Detection of antibodies to Francisella tularensis in cats. Res Vet Sci 82:22-26. https://doi. org/10.1016/j.rvsc.2006.06.003
Maurin M (2015) Francisella tularensis as a potential agent of bioterrorism? Expert Rev Anti-Infect Ther 13(2):141-144. https://doi.org/10. 1586/14787210.2015.986463

Maurin M, Pelloux I, Brion JP, Del Banõ JN, Picard A (2011) Human tularemia in France, 2006-2010. Clin Infect Dis 53:133-141. https:// doi.org/10.1093/cid/cir612

Melikjanyan S, Palayan K, Vanyan A, Avetisyan L, Bakunts N, Kotanyan M, Guerra M (2017) Human cases of tularemia in Armenia, 1996-2012. Am J Trop Med Hyg 97:819-825. https:// doi.org/10.4269/ajtmh.16-0605

Mohamed Salma ER, Mubarak Aymun I, Alfarooq Lamia O (2012) Francisella tularensis bacteremia: a case report from Sudan. Case Rep Infect Dis 405737:1-2. https://doi.org/10.1155/2012/405737

Moniuszko A, Zajkowska J, Pancewicz S, Kondrusik M, Grygorczuk S, Czupryna P (2011) Arthropod-borne tularemia in Poland: a case report. Vector Borne Zoonotic Dis 10:1399-1401. https://doi.org/ $10.1089 / \mathrm{vbz} .2010 .0227$

Mörner T (1992) The ecology of tularemia. Rev Sci Tech 11:1123-1130

Mörner T, Addison E (2001) Tularemia. Infectious diseases of wild mammals. State Press, Iowa

Mörner T, Mattsson R (1983) Tularemia in a rough-legged buzzard (Buteo lagopus) and a Ural owl (Strix uralensis). J Wildl Dis 19(4):360-361

Mörner T, Sandström G, Mattsson R, Nilsson P (1988) Infections with Francisella tularensis biovar palaearctica in hares (Lepus tumidus, Lepus europaeus) from Sweden. J Wildl Dis 24:422-433. https:// doi.org/10.7589/0090-3558-24.3.422

Müller W, Hotzel H, Otto P, Karger A, Bettin B, Bocklisch H, Braune S, Eskens U, Hörmansdorfer S, Konrad R, Nesseler A, Peters M, Runge M, Schmoock G, Schwarz BA, Sting R, Myrtennäs K, Karlsson E, Forsman M, Tomaso H (2013) German Francisella tularensis isolates from European brown hares (Lepus europaeus) reveal genetic and phenotypic diversity. BMC Microbiol 13:61. https://doi.org/10.1186/1471-2180-13-61

Nakamura K, Fujita H, Miura T, Igata Y, Narita M, Monma N, Hara Y, Saito K, Matsumoto A, Kanemitsu K (2018) A case of typhoidal tularemia in a male Japanese farmer. Int J Infect Dis 71:56-58. https://doi.org/10.1016/j.ijid.2018.03.023

Nejeru J, Tomaso H, Mertens K, Henning K, Wareth G, Heller R, Kariuki S, Fevre EM, Neubauer H, Pletz MW (2017) Serological evidence of Francisella tularensis in febrile patients seeking treatment at remote hospitals, northeastern Kenya, 2014-2015. New Microbe and New Infect 19:62-66. https://doi.org/10.1016/j.nmni.2017.05.015

Nordstoga A, Handeland K, Johansen TB, Iversen L, Gavier-Widen D, Mattsson R et al (2014) Tularaemia in Norwegian dogs. Vet Microbiol 173:318-322. https://doi.org/10.1016/j.vetmic.2014.06.031

Office International des Epizooties (2005) World Animal Health Publication and OIE Handistatus II: Tularemia. http://web.oie.int/ hs $2 /$ report.asp

Office International des Epizooties (2009) OIE 2005-2009 (Hand status), Manual of standards for diagnostic tests and vaccines: for terrestrial animals (mammals, birds and bees).https://www.oie.int/doc/ged/ D7710.PDF

Ogden NH, Artsob H, Margos G, Tsao J (2014) Non-rickettsial tickborne bacteria and the diseases they cause, Biology of ticks ( 2 nd ed.). New York. Oxford University Press

Ohara Y, Sato T, Homma M (1998) Arthropod-borne tularemia in Japan: clinical analysis of 1374 cases observed between 1924-1996. J Med Entomol 35:471-473. https://doi.org/10.1093/jmedent/35.4.471

Ohlin G (1942) Occurrence and mode of transmission of tularaemia in Sweden. Acta Microbiol Scand 19:220-247

Olsuf'ev NG, Shlygina KN (1979) Role of cannabalism in the development of tularemia with nonlethal outcome in common voles highly sensitive to tularemia. Zoologicheskii Zhurnal 58:933-936

Olsufiev NG (1977) Results and perspectives of the study of natural foci of tularemia in USSR. Med Parazitol (Mosk) 46:273-282 
Origgi FC, Frey J, Pilo P (2014) Characterisation of a new group of Francisella tularensis subsp. holarctica in Switzerland with altered antimicrobial susceptibilities, 1996 to 2013. Euro Surveill 19 (29): pii: 20858. doi: https://doi.org/10.2807/1560-7917.es2014.19.29.20858

Orkun O, Karaer Z, Cakmak A, Nalbantoglu S (2014) Identification of tick-borne pathogens in ticks feeding on humans in Turkey. Plos NTD 8(8):3067. https://doi.org/10.1371/journal.pntd.0003067

O'Toole D, Williams ES, Woods LW, Mills K, Boerger-Fields A, Montgomery DL, Jaeger P, Edwards WH, Christensen D, Marlatt W (2008) Tularemia in range sheep: an overlooked syndrome? J Vet Diagn Invest 20:508-513. https://doi.org/10.1177/ 104063870802000417

Oyston PCF, Quarry E (2005) Tularemia vaccine: past, present and future. Antonie Van Leeuwenhoek 87:277-281. https://doi.org/10. 1007/s10482-004-6251-7

Ozkok A, Karadenizli A, Odabas AR (2012) Tularemia in a kidney transplant recipient. Am J Kidney Dis 60:679. https://doi.org/10.1053/j. ajkd.2012.06.023

Padeshki PI, Ivanov IN, Popov B, Kantardjiev TV (2010) The role of birds in dissemination of Francisella tularensis: first direct molecular evidence for bird-to-human transmission. Epidemiol Infect 138: 376-379. https://doi.org/10.1017/S0950268809990513

Pavlovsky E (1966) Natural nidality of transmissible diseases. IL Univ. Ill. Press, Urbana

Pearson AP (1998) Tularemia. Zoonoses: biology, clinical practice, and public health control. UK, Oxford University Press

Penn RL (1994) Francisella tularensis (Tularemia). In: Wintrobe MM, Thorn GW, Adams RD, Benett IL, BraunwaldE, Isselbacher KJ et al. (Eds). Harrison's principles of internal medicine. New York: McGraw-Hill pp: 2060-2067

Petrishcheva PA (1965) Vectors of diseases of natural foci. Vol. 54. Israel Program for Scientific Translation, Jerusalem

Pilo P (2018) Phylogenetic lineages of Francisella tularensis in animals. Front Cell Infect Microbiol 8:258. https://doi.org/10.3389/fcimb

Plourde PJ, Embree J, Friesen F, Lindsay G, Williams T (1992) Glandular tularemia with typhoidal features in a Manitoba child. CMAJ 146: 1953-1955

Reintjes R, Dedushaj I, Gjini A, Jorgensen TR, Cotter B, Lieftucht A, D'Ancona F, Dennis DT, Kosoy MA, Mulliqi-Osmani G, Grunow R, Kalaveshi A, Gashi L, Humolli I (2002) Tularemia outbreak investigation in Kosovo: case control and environmental studies. Emerg Infect Dis 8:69-73

Robert Koch Institute (2017) Infektionsepidemiologisches Jahrbuch meldepflichtiger Krankheiten für 2016. (Article in German). http:// www.rki.de/DE/Content/Infekt/Jahrbuch/Jahrbuch_2016.pdf? blob=publicationFile

Rossow H, Sissonen S, Koskela KA, Kinnunen PM, Hemmila H, Niemimaa J, Huitu O, Kuusi M, Vapalahti O, Henttonen H, Nikkari S (2014) Detection of Francisellatularensis in voles in Finland. Vector Borne Zoonotic Dis 14:193-198. https://doi.org/ 10.1089/vbz.2012.1255

Rydén P, Björk R, Schäfer ML, Lundström JO, Petersén B, Lindblom A, Forsman M, Anders Sjostedt A, Johansson A (2011) Outbreaks of tularemia in a boreal forest region depends on mosquito prevalence. J Infect Dis 205:297-304. https://doi.org/10.1093/infdis/jir732

Sadiku I, Bajrami M, Ramadani H, Mehmeti M, Ponosheci A, Berisha V (2015) Tularemia in children in Kosovo from November 2014March 2015. 8th International Conference on, Opatija, Croatia, Sept28-Oct1. https://www.tularemianetwork.com/Tularemia/EN/ Events/Program_Agenda_Abstract_Book.pdf?_blob= publicationFile

Șahin İ (2009) Tulareminin Genel Epidemiyolojik Özellikleri: Francisella tularensis ve Tularemi. İstanbul, Nobel Tip Kitabevleri

Sandström G, Sjöstedt A, Forsman M, Pavlovich NV, Mishankin BN (1992) Characterization and classification of strains of Francisella tularensis isolated in the central Asian focus of the Soviet Union and in Japan. J Clin Microbiol 30:172-175

Scheftel JM, Griffith JM, Leppke BA, Pantlin GC et al (2010) Tularaemia in Minnesota: case report and brief epidemiology. Zoonoses Public Health 57:165-169. https://doi.org/10.1111/j.1863-2378.2009.01318

Shoemaker D, Woolf A, Kirkpatrick R, Cooper M (1997) Humoral immune response of cottontail rabbits naturally infected with Francisella tularensis in southern Illinois. J Wildl Dis 33:733737. https://doi.org/10.7589/0090-3558-33.4.733

Siddaramappa S, Challacombe JF, Petersen JM, Pillai S, Hogg G, Kuske CR (2011) Common ancestry and novel genetic traits of Francisella novicida-like isolates from North America and Australia as revealed by comparative genomic analyses. Appl Environ Microbiol 77: 5110-5122. https://doi.org/10.1128/AEM.00337-11

Sinclair JR, Newton A, Hinshaw K, Fraser G, Ross P, Chernak E, Johnson C, Warren N (2008) Tularemia in a park, Philadelphia, Pennsylvania. Emerg Infect Dis 14:1482-1483. https://doi.org/10. 3201/eid1409.071690

Sjödin A, Svensson K, Öhrman C, Ahlinder J, Lindgren P, Duodu S, Johansson A, Colquhoun DJ, Larsson P, Forsman M (2012) Genome characterisation of the genus Francisella reveals insight into similar evolutionary paths in pathogens of mammals and fish. BMC Genomics 13:268. https://doi.org/10.1186/1471-2164-13-268

Sjöstedt A (2005) Family XVII. Francisellaceae, genus I. In: Francisella: Bergey's manual of systematic bacteriology, 2nd edn. Springer, New York

Sjöstedt A (2007a) Tularemia: history, epidemiology, pathogen physiology and clinical manifestations. Ann N Y Acad Sci 1105:1-29. https://doi.org/10.1196/annals.1409.009

Sjöstedt A (2007b) Epidemiology: WHO guidelines on tularemia. https:// www.who.int/csr/resources/publications/WHO CDS EPR 20077. pdf?ua $=1$

Sjöstedt A (2016) Clinical manifestations and the epidemiology of tularemia. Med Flum 52(2):211-216. https://doi.org/10.1196/annals. 1409.009

Staples JE, Kubota KA, Chalcraft LG, Mead PS, Petersen JM (2006) Epidemiologic and molecular analysis of human tularemia, United States, 1964-2004. Emerg Infect Dis 12:1113-1118. https://doi.org/ 10.3201/eid1207.051504

Syrjala H, Kujala P, Myllyla V, Salminen A (1985) Airborne transmission of tularemia in farmers. Scand J Infect Dis 17:371-375. https:// doi.org/10.3109/13813458509058777

Tärnvik A, Chu MC (2007) New approaches to diagnosis and therapy of tularemia. Ann N Y Acad Sci 1105:378-404. https://doi.org/10. 1196/annals.1409.017

Taylor JP, Istre GR, McChesney TC, Satalowich FT et al (1991) Epidemiologic characteristics of human tularemia in the southwest-central states, 1981-1987. Am J Epidemiol 133:10321038. https://doi.org/10.1093/oxfordjournals.aje.a115812

Telford SR, Goethert HK (2020) Ecology of Francisella tularensis. Annu Rev Entomol 65:351-372. https://doi.org/10.1146/annurev-ento011019-025134

Tigertt WD (1962) Soviet viable Pasteurella tularensis vaccines: a review of selected articles. Bacteriol Rev 26:354-373

Titball RW, Sjostedt A (2003) Francisella tularensis: an overview. ASM News 69:558-563

Uncu M, Süer K, Kocaoğlu M, Șafak MA, Çağlar K (2017) Case report of systemic tularemia in Cyprus. Cyprus J Med Sci 2:81-84. https:// doi.org/10.5152/cjms.2018.301

Valentino MD, Hensley LL, Skrombolas D, McPherson PL, Woolard MD, Kawula TH et al (2009) Identification of a dominant CD4 Tcell epitope in the membrane lipoprotein Tul4 from Francisella tularensis LVS. Mol Immunol 46:1830-1838. https://doi.org/10. 1016/j.molimm.2009.01.008

Wang Y, Peng Y, Hai R, Xia L, Li H, Zhang Z, Cai H, Liang Y, Shen X, Yu D, Birdsell D, Wagner DM, Keim P (2014) Diversity of 
Francisella tularensis subsp. holarctica lineages, China. Emerg Infect Dis 20:1191-1194. https://doi.org/10.3201/eid2007.130931

Whipp MJ, Davis JM, Lum G, Boer J, Zhou Y, Bearden SW, Petersen JM, Chu MC, Hogg G (2003) Characterization of a novicida-like subspecies of Francisella tularensis isolated in Australia. J Med Microbiol 52:839-842. https://doi.org/10.1099/jmm.0.05245-0

Wobeser G, Campbell GD, Dallaire A, McBurney S (2009) Tularemia, plague, yersiniosis, and Tyzzer's disease in wild rodents and lagomorphs in Canada: a review. Can Vet J 50:1251-1256
World Health Organization (WHO) (2007) Guidelines on Tularaemia, Geneva, WHO Press.https://www.who.int/csr/resources/ publications/WHO_CDS_EPR_2007_7.pdf?ua=1

Zargar A, Maurin M, Mostafavi E (2015) Tularemia, a re-emerging infectious disease in Iran and neighboring countries. Epidemiol Health 22(37):e2015011. https://doi.org/10.4178/epih/e2015011

Publisher's note Springer Nature remains neutral with regard to jurisdictional claims in published maps and institutional affiliations. 